\title{
Minhocão: affective re-territorializations in contemporary urban disputes
}

\author{
Minhocão: reterritorializações afetivas \\ nas disputas urbanas contemporâneas
}

Eliana Rosa de Queiroz Barbosa [I] Cintia Elisa de Castro Marino [II]

\begin{abstract}
This paper presents a case of urban dispute to show how a new political body has been affectively occupying the spheres of participation since the uprisings that occurred in Brazil in June 2013. Minhocão, the target of this urban dispute, is an elevated highway located in the city of São Paulo. Inaugurated in 1970, it has been informally occupied by the inhabitants of its surroundings since the 1980s. Using the notion of "affective re-territorializations" (Hutta, 2019), the article analyses how the rise of conservative and progressive affective fields are reshaping spaces in the contemporary city and, ultimately, influencing urban projects and public policies. Through the analysis of primary and secondary data, the article demonstrates that this space, which used to be the target of informal appropriations, has become the symbol of an affective dispute, being constantly re-signified, alternating progressive and reactionary ideologies.
\end{abstract}

Keywords: protests; affection; Minhocão; urban dispute; re-territorialization.

\section{Resumo}

0 artigo apresenta um caso de disputa urbana, demonstrando como um novo corpo político tem ocupado afetivamente as esferas de participação desde as manifestações brasileiras de junho de 2013. O Minhocão, alvo dessa disputa urbana, é uma via expressa elevada, localizada no município de São Paulo, inaugurada em 1970 e ocupada informalmente pelos moradores do entorno desde a década de 1980. A partir da noção de "reterritorializações afetivas" (Hutta, 2019), o artigo analisa como a ascensão de campos afetivos conservadores e progressistas estão remodelando espaços na cidade contemporânea e, em última instância, influenciando projetos urbanos e políticas públicas. Por meio da análise de dados primários e secundários, o artigo demonstra que esse espaço, outrora alvo de apropriações informais, passou a ser símbolo de uma disputa afetiva, sendo constantemente ressignificado, alternando ideologias progressistas e reacionárias.

Palavras-chave: manifestações; afeto, Minhocão; disputa urbana; reterritorialização. 


\section{Introducing Minhocão and its urban dispute}

The elevated highway popularly known as Minhocão is a three and a half kilometer long inner-city expressway, elevated five meters from the ground, cutting through three different neighborhoods in downtown São Paulo, Brazil. Since its construction in the early 1970s, under mayor Paulo Maluf's mandate ${ }^{1}$ during the military dictatorship, this brutal concrete-made piece of infrastructure faced opposition due to its visual, social and economic impacts (Artigas et al., 2008). In 1976, it first was closed to motorized traffic in the nighttime, in response to mounting popular pressure and, from 1989 onward, an executive decree issued by the left-wing Workers' Party (PT) mayor Luiza Erundina defined fixed weekly closure times. Since then, it has been informally appropriated for leisure activities by surrounding residents, embracing different territorial meanings and interpretations (Barbosa, 2012; Marino, 2019).

This research aims to interpret the recent urban dispute involving Minhocão, triggered by Bill 10/2014, aimed at changing its elevated highway status within the legislative and administrative bodies of the city. We see this dispute as one of the many affected by the political polarization that has been mounting since the Brazilian demonstrations of June 2013.

Colored by different actors that have been occupying multiple spheres of participation since the protests, this paper documents the increasing speculations that unfolded into this urban dispute. Since 2012, a sequence of events placed Minhocão at the center of discussion, as the object of associactivism groups and urban appropriations, awakening diverse (conflicting) socio-political constellations, embodying an increasing urban dispute and, ultimately, influencing urban projects and policies.

The demonstrations of June 2013 saw the political body occupying the public sphere, exposing Brazil's political divide and paving the way to an increased presence of emerging conservative groups in public debates. ${ }^{2}$ Similar processes of discontent happened simultaneously in many countries, pointing to a generalized disbelief in the traditional systems of representative democracy and the emergence of right-wing populism. This conjuncture suggests that representative democracy is being challenged amid neoliberalization processes ${ }^{3}$ at large and their consequences materialized in space ${ }^{4}$ (Santos, 2015; Pinson and Journel, 2016; Bauman and Mauro, 2018).

The recent urban dispute over Minhocão implies the emergence of a new phenomenon, intertwining civic participation and new forms of occupation of the public realm (in a wider sense) in the Brazilian cities. Taking on the case of Minhocão and the dispute around its future, we explore a hypothesis that the urban uprisings of the early 2010s changed how different actors position themselves, both physically and virtually, in the public realm (Carlos, 2014; Pinto, 2017; Monteiro, 2018).

This paper aims to shed a light on the urban dispute that culminated in the executive decision of formalizing the occupation of Minhocão, turning it into a park. It also documents and analyzes how these (online and offline) affective performances have mobilized the dispute within the official channels of participation and in the public 
space in question. We present how progressive and conservative agendas (aimed at expanding and restricting rights, respectively) were pushed forward by means of affective performances, arguing that this exemplifies how the conservative and progressive bold affects (Hutta, 2019) of contemporaneity are re-shaping spaces in the city and, ultimately, influencing projects and policies .

Methodology-wise, the paper articulates the narratives and actions of the groups involved in this dispute, especially founders and active leaders, involving participant observation in the events described, in-depth interviews with stakeholders and members of the different groups, as well as analysis of their institutional discourse supporting this dispute. Additionally, we consulted and analyzed official documents generated during the dispute, such as bills, and transcripts of public hearings and administrative processes. Since a great deal of the dispute occupied online spheres, we revised online publications, discussion forums and social media posts from the different groups and movements involved. The online interaction also involved understanding how the different groups interacted with traditional media pieces reporting on the dispute. Data collection occurred within different periods between 2011 and 2018.

This paper is organized in four sections, in addition to the introduction and the conclusion. First, we explore how the 2013 urban protests in Brazil conceptually framed the contemporary urban dispute involving Minhocão. Second, we present the emerging social constellations, the rise of different associactivisms acting on the urban dispute of Minhocão that started with the consultations for Bill 10/2014. The third section frames the dispute, analyzing how the different stakeholders positioned themselves in relation to the public policies and projects. The fourth section reveals how contemporary bold affects are re-territorializing spaces in the city and ultimately influencing projects and policies.

\section{The body in the city: social media, uprisings, and the contemporary urban dispute}

The censorship and persecution promoted during the military regime in Brazil (19641985) had strong cultural, artistic and social impact, affecting particularly how Brazilians relate to the different instances of power, use the different instances of public participation and, ultimately, occupy public spaces. The use of public spaces during this time was controlled. Any public demonstration of discontent was obstructed or banned over two decades. Protests resurfaced in the 1980s with the democratization process, a period marked by the action of workers' unions, urban and rural social movements, which presented a complex organizational structure. In this context, guidelines for claiming the right to the city were brought up with the aim of reversing social inequalities. It would be the right to human emancipation. Since then, social movements have been struggling to strengthen public services, social protection and labor regulations (Lefebvre, 1972; Souza and Rodrigues, 2004).

Following a global trend, along the late 2000s and early 2010s, Brazilian mobilizations clearly intensified with the advent of online tools (Wisnik, 2016). All sorts of different civil 
society organizations emerged in São Paulo, framed here as associativisms (broadly studied by Hirst, 1994, 2001; Cohen and Rogers, 1995; Warren, 2001). Virtually organized, collectively funded and related to mobility, arts and culture, most of these associactivism groups foregrounded public spaces and the appropriation of the city as their main agenda (Catarse and Chorus, 2014). Such mobilizations for the right to the city establish sectoral and territorial dialogues, in order to bring back idealism for a more just society (Miraftab, 2016; 2009).

However, the movement of strengthening community initiatives and associations shows certain limits. Groups acting in the urban space are inherently exclusionary as there is no such thing as "the people" (Butler, 2016). Moreover, not all organizations are engaged in reversing socio-territorial disparities, and often solutions proposed in the local scale cannot be scaled up nor weigh in the importance of demands from unorganized actors (Miraftab, 2009; Harvey, 2012).

In November 2012, after a disputed election, in which different models of urban space appropriation were intensively debated, the left-wing mayor Fernando Haddad was elected, after eight years of right-wing administration. His first actions defined a new set of guidelines for the participatory revision of the masterplan. The mayor also raised the bus fare in 20 cents of the Brazilian Real, triggering civil society's reaction in an unforeseen scale throughout the country.

A societal turning point, the Brazilian protests of June 2013 were a major complex phenomenon that still reverberates politically.
They are part of the several uprisings of the early 2010s that emerged all over the globe. First taken as a worldwide movement of hope, these different urban demonstrations, highly mediated by social media and their possibilities of mobilizing affects toward political causes, also triggered the rise of conservative movements occupying the global public sphere.

In Brazil, the protests started in São Paulo were based on concrete mobility demands promoted by a civil society organization called Movimento Passe Livre, whose agenda is clear: free universal public transportation (Vainer, 2013; Schwarcz and Starling, 2015, Machado, 2019). Those were not the first protests promoted by the movement in the city and, initially, they focused on mobility policies, the models of public transport concessions and the price and quality of the public transport system in São Paulo. As in other occasions, the most important traditional media outlets depicted participants and their actions negatively, while the police repressed them with violence.

On the $13^{\text {th }}$ of June 2013 , during the second protest in São Paulo, a female reporter was heavily injured by the police. The photo of a young reporter hit in the face by a rubber bullet while covering the protest for one of the top national newspapers circulated quickly. This represented a turning point in media discourse that triggered a range of reactions from civil society. Starting as a specific urban demand - improvements on mobility - the protests' agenda became diffuse: anti-violence, anti-police, anti-corruption, anti-government, anti-politics, anti "everything that is going on", showing general dissatisfaction with representative democracy. 
A similar climate was observed in worldwide protests between 2009 and 2015, such as in Middle East countries, commonly described as the Arab Spring; in Spain with the Indignados Movement; or the Occupy Wall Street Movement in New York, where citizens expressed dissatisfaction with their government system (Castells, 2015; Santos, 2015; Butler, 2015). What they have in common is a desire by protesters to exercise a collective right to shape the city. They are looking for a sense of belonging to a political community that can act directly upon the public space. The logic involves a social sense different from state provision mediated by representatives, where collective social claims are based on aspects such as participation, provision and regulation (Harvey, 2012; 2008). Those protests, on the other hand, express a contradictory view, as the idea of "dignity" or "indignation" is widely present and much more centered on emotion than reason. These movements often demand structural changes, but lack answers, solid work or continuity to their commitment (Zizek, 2012; Bauman and Mauro, 2018).

There are several ways of understanding the social and political meanings of these protests in Brazil. The main mobilization did not come from the collaboration of parties and unions, it was an intense seizure of the entire political spectrum, from right to left, which aroused controversy about the socioideological composition of the demonstrators and triggered a wave of uncertainties (Maricato et al., 2013). An early interpretation came from Carlos (2014a, 2014b), reflecting that the middle class occupied the streets in Brazil again after a long period of dormancy. Urban social movements had a history of raising awareness through protests, making all sorts of social demands concerning the right to the city, mainly focusing on housing, urban and agrarian land reforms. However, Carlos states that the June 2013 protests represented the conflicting entirety of the societal political body occupying the city, claiming their space in the public sphere in mass-scale. She highlights that the protests took place in the time and space of daily life, where public life and its struggles happens. Her hypothesis suggested the emergence of a new and more diverse political body occupying the streets, changing the way society civically engages with its urban spaces. Later on, other authors joined in.

Focused on the roles of social media, Jardim Pinto (2017) examined the trajectory of the discourse triggered by the June 2013 protests, which underwent some transformations in 2014 and culminated in the pro-impeachment rhetoric of the 2015 demonstrations, using social media as a platform to summon and organize public gatherings. The author suggests that there was an alteration of the discourse: from traditional social demands for rights, it veered toward a reactionary agenda that culminated in the ouster of thenpresident Dilma Roussef. Since the early $80 \mathrm{~s}$, known as the period of re-democratization, street protests had been mainly organized by leftist groups. From 2013 and increasingly since 2014 , protests have mobilized masses that had not been physically present in the urban realm before. After thirteen years of Workers' Party (PT) governments (2003 to 2016), there was a discursive displacement toward a conservative direction based on anti-PT sentiments and protesters increasingly tended to identify with center-right, right-wing and far-right political positions. 
The fragmentation of agendas in June 2013 is perceived as a new phenomenon, by which the gathering of masses with remarkably diverse agendas meant there was no clear ideological demand, but an affective performance in the public sphere. Pinto (2017) suggests that the anti-partisan sentiment of dissatisfaction that marked June 2013 evolved gradually and new (conservative) signifiers flourished from the fragmentation of the progressive agenda. According to Schwarcz and Starling (2015), the leftist demands strengthened in the period are related to "rights to difference", such as the black, LGBTQ, feminist movements, etc. While left-leaning movements fought for the "rights to difference", the new reactionary signifiers articulated a political discourse unconcerned with social rights, quite the opposite: they mobilized public forces for their removal. This meant the emergency of a new political subject in the streets (understood in a physical and conceptual space), positioned to the right of the political spectrum in the ideological arena, mobilizing resentment and affectively demanding fewer rights and less freedom.

Butler (2015) argues that as a result of of bodies assembling in the streets, new political spaces are created. She describes the implications of an embodied, plural performativity that emerges from this type of public assembly, also mobilized by "a complex interplay of performance/image, acoustics, and all the various technologies" (p. 20).

Regarding Butler's argument on the right of rights (resuming a discussion started by Hannah Arendt), the constitution of the public sphere as a political space relies on the performative embodiment of claims. The demonstrations performatively claim the plural right to appear, to be present in the streets, to maintain the communal possibility of being: "The right comes into being when it is exercised, and exercised by those who act in concert, in alliance" (p. 81).

Allied with this view of performance and spatial dispute, Monteiro (2018) explains June 2013 as the moment when new forms of communication and organization emerged, offering more dynamic tools to engage the "multitude". The "multitude" and the "streets" are interpreted here as wide-ranging categories in a social spatial context, based on the prerogative that they are heterogeneous, mixed, contradictory, conflicting and in dispute. In this case, "multitude" and "streets" represent an urban dispute that does not reflect different ideological spectrums, rather a struggle between them, with methods constantly under construction, deconstruction, reconstruction, cooptation, and corruption. Monteiro concludes by explaining that a new "spirit" was created in June 2013 that remains alive through social media, communication devices and networks, as a form of affective contagion.

This new spirit is also mentioned by Pinheiro-Machado (2019). Researching different emerging phenomena since June 2013, she discusses how the different movements reinvent the meanings of common collective goods, reinforcing the importance of being together and forging new forms of sociability, producing entertainment, art, culture and creating spaces of exchange. According to the author, the global spring of demonstrations represented, at the same time, social rupture and cohesion of the social 
and political orders, pointing to new forms of engaging in and with the public sphere, based on micropolitics, creativity, decentralization and radical affects.

Following the importance of radical affects in dealing with contemporary urban disputes, we highlight Jan Simon Hutta's notion of bold affects in processes of affective re-territorialization applied to the current Brazilian political context. Based on the distinction of territory and territoriality defined by Haesbaert (2013), Hutta conceives territorializing spaces as "generating the material and semiotic conditions for inhabiting spaces" (Hutta, 2019, s/p). The notion of affective territorialization (and re-territorialization) refers, therefore, to the construction, deconstruction and reconstruction of symbolic affective meanings of the urban spaces and the public sphere. Thus, affective de- and re-territorializations occur when distinct social actors affectively perform on the streets, on public spaces and in different official instances of participation, changing the conditions of inhabiting these spaces. In these affective re- and de-territorialization performances based on bold affects, enactments of hope, joy, anger, disenchantment, fear, among other sentiments can be mobilized by progressive and reactionary ideologies. We incorporate Hutta's argument, understanding that bold affects, when performed in public spaces, have the power to de- and re-territorialize these spaces.

Sandler (2020), while discussing this multitude of actions in the context of São Paulo, frames it as examples of grassroots urbanisms, by which emerging creative interventions in communal and public spaces in the city have been simultaneously influencing social imaginaries, generating expectations and speculations and ultimately, framing urban policies. Sandler (2020) concludes that the significant ways by which grassroots urbanism can make a difference is by portraying a multitude of urban futures for city residents, expanding their repertoire for alternative urban lives. In the context of a divided society such as the Brazilian one, we add that expanding the repertoire toward possible urban futures can be an activity rife of conflict, leading to urban disputes. We argue that the way these disputes unfolded in public spheres of participation has changed substantially after the June 2013 demonstrations in Brazil.

At that moment, these conservative and progressive forces coincided briefly in space and time, aiming to re-territorialize the same urban spaces by affectively occupying the streets (Hutta, 2019). These affective performances constantly re-territorialized spaces in the public realm at the time. However, we argue here that hey never left the "streets", in its figurative and literal senses. Since then, they continue to reverberate or contaminate. To use Monteiro's term, their physical and virtual presence in the urban realm remains to this today.

Thus, we propose a reading of this dispute by understanding the new diverse and conflicting political body that occupies the contemporary urban realm as suggested by Carlos (2014a, 2014b), acknowledging that the dispute occupies physical and online instances and social media is a key element to understand it, as it helps assemble and mobilize groups of individuals with shared interests (Pinto, 2017; Butler, 2016). These online and physical mobilizations promote 
affective contagion (Monteiro, 2018); therefore, affect is a key element to read these disputes. Moreover, when reading urban disputes through these lenses, it bears noting that the rise of conservative rhetoric and demands is based on the proposed removal of rights as opposed to the demands for rights made by the progressives (Pinto, 2017).

We understand that the phenomenon of re-territorializing spaces in the city incurs in the creation of new affective territorialities, as suggested by Hutta (2019). Most importantly, we propose here that bold affects and their re-territorializations have left the space and time of the events and entered the different spaces of day-to-day urban disputes. Affective re-territorializations by means of performed bold affects are now daily political strategies of space transformation that can be used both by progressive and conservative forces. We propose that the lenses of reterritorializations, caused by the performance of bold affects in public spaces, explain how these contemporary urban disputes unfold.

We acknowledge that there is a wider dispute at stake, when it comes to the center of São Paulo, involving all sorts of disenfranchised people (the increasing homeless population, the organized sem teto movement in the housing occupations, residents of derelict tenements, pressured lower class tenants, lower income LGBTQ population, migrant workers, among others), ongoing gentrification processes, state repression, police violence, under a neoliberalization process. Moreover, we acknowledge that this wider dispute impacts and is impacted by the dispute regarding the formalization - or not - of Minhocão as a park. Yet, for the purpose of clarity, in this paper we intentionally focus on the dispute around Bill 10/2014 for our analysis. If performed bold affects are capable of re-territorializing urban spaces and if rights come into being when exercised in alliance, meaning, if exercised by a recognizable group of individuals as Butler (2016) suggests, how have these affective performances mobilized this particular dispute?

We recognize Butler's take on the exclusive aspects of the groups involved in the demonstrations, and the fact that the very "public sphere" considered here (online forums, social media pages, public hearings, the space of Minhocão when used as a park, and so on) is defined and constituted by the exclusion of the disenfranchised. This is a middle class dispute. Yet, as Carlos stated (2014a) right after June 2013, all possible political (and economic) bodies are now in "the streets" in its wider sense (Monteiro, 2018). The novelty here is the rising appearance of the middle class in public space disputes, mobilizing tactics that, up until recently, were more commonly used by the disenfranchised.

\section{The emerging (opposing) social constellations of Minhocão}

Informally occupied for leisure by its residents since the 1980s, Minhocão had never been much of a subject of discussion in public hearings until the early 2010s. Its construction was heavily criticized from the beginning and all kinds of speculation regarding its future have often emerged in the media; however, nothing actually materialized. Until the 2010s, the multiple meanings that Minhocão took on 
represented, from a "top down" perspective, a terrible loss of financial value for owners of the surrounding properties and a damage-prone, replaceable piece of urban infrastructure for planners. It was also taken as social infrastructure, due to its appropriation by citizens that claimed its space as their "place" (Barbosa, 2012). This opposition between the conservative and technical standpoint versus the positive attitude of the residents surrounding Minhocão became more complex after June 2013.

The early 2010s represented the rise of different associactivisms that steered different actions in the public spaces. In São Paulo, one of these emerging groups was called Baixo Centro. Its actions directly affected the future of Minhocão. Between 2011 and 2014, this group produced several events featuring artistic occupations and temporary interventions, seeking community engagement and promoting the ludic slogan "the streets are made for dancing".

Baixo Centro started as a group of young cultural producers coming together to organize an urban art festival in Santa Cecília, one the neighborhoods surrounding Minhocão. From its kickstart at Casa de Cultura Digital, a local cultural hub and the base for several artists and cultural producers, Baixo Centro slowly became a vast group of diverse people, horizontally organized through social media platforms such as Twitter, Facebook and Google Groups. ${ }^{5}$

This group collaboratively carried out several initiatives to occupy Minhocão and other public spaces in the São Paulo downtown area. In their temporary interventions, they used artificial grass, beach chairs and collapsible pools. In April 2012, a major collaborative event was crowdfunded for the first time, organized and promoted through social media. Minhocão and its surrounding areas in the Santa Cecillia neighborhood hosted most of the festival's program, which was a public attendance success, and received a great deal of media attention, being depicted in the front cover of the two top newspapers in its last day.

Since this event, Minhocão became a popular place in the city. In 2012, some months later, its space was for the first time in ten years used as a site of Virada Cultural, the most important official cultural event of São Paulo, a program of 24 hours of cultural activities and performances spread through the downtown neighborhoods, organized by the municipality.

After the combination of the Virada Cultural and Baixo Centro festivals, Minhocão began to constantly host informal events, attracting wider crowds and an increasing flow of visitors from outside of its surrounding neighborhoods. For three consecutive years, Baixo Centro produced a collaborative and crowdfunded festival in the streets, with dozens of free cultural activities and performances.

In addition to the festivals, the movement organized events such as Festa Junina - a popular, folkloric Brazilian celebration traditionally held in June and July - encouraging the appropriation of the public space and fostering cooperation among local communities. As a horizontal group, the members of Baixo Centro did not want to acquire any institutional character as an organization. Activists were surprised by the massive presence of young people from other parts of the city and noticed that 
Minhocão was gaining visibility. After three years of yearly festivals and events, the group dispersed and decided, for various reasons, to stop organizing events in 2016 (Baixo Centro Activist, 2017).

The important contribution of Baixo Centro was changing the residents' perspective about the possibilities of acting in the streets. The publication that they issued, entitled "Steps for dancing" [Passos para dançar] compiled different steps to guarantee the safety of the people performing in the streets and public spaces surrounding Minhocão. The publication offered a manual, containing the constitutional articles and the municipal regulation that protected and guaranteed the legality of the participants' presence in public spaces. Their call for performative bold affects was clear:

The street is collectivity, gathering, collaboration. We must do it together: we act and gather by being together. (...) The reality is less dreamt than tried. It is a reaction... So, propose something before you try anything else! After learning the steps of the dance (and the integrity that we all must have to propose an action in the public space), it is time to improvise the dance! Be collective, exaggerate, look around, do not be embarrassed, look closely and perform! (Baixo Centro, 2013)

Being in the spotlight, Minhocão started to attract the multitude, as coined by Monteiro (2017). In August 2013, roughly two months after the June protests, the Associação Parque Minhocão was officially created, after operating informally for some months, gathering residents, artists, intellectuals, activists, politicians, and architects enthusiastic of the idea of turning Minhocão into an official elevated park.

The Associação Parque Minhocão emerged not as a neighborhood association, but as a group of activists who had a welldefined agenda: the creation of a park on the elevated highway (Levy, 2014; 2015; Comolatti et al., 2014). It was funded as a formal legal entity, fulfilling all legal requirements to represent civil society, by an entrepreneur who was acting president for its first years (20132016). His initiative was very influenced by the High Line Park experience in New York.

The Association had its own headquarters - an apartment facing Minhocão -, a website, ${ }^{6}$ a Facebook page and a Facebook group. It did not promote direct actions and events in Minhocão, but supported the individuals or groups that wanted to use it as a public space, respecting the existing regulations for formal public spaces in the city concerning noise limits, opening hours, permitted activities, among others. The group involved in the association's foundation understood from the beginning that being a formal and legally recognized entity was important to make sure they could take part in the official political debate and spheres of participation. During the São Paulo Architecture Biennial of 2013, the association hosted an exhibition about New York's High Line Park in its headquarters. The apartment, right next to Minhocão, offered by the association's founder, illustrated the possibilities of transformation of the highway.

The temporary exhibition provided an overview of the High Line Park experience with photographs and narratives. In addition to that, it showed a large three-dimensional model of Minhocão and its surrounding buildings, and a series of ludic drawings entitled "Parque 
Minhocão Project" made by an artist, architect and member of the association. The visits were restricted to groups of six at a time. The Biennial also set up a swimming pool on top of the structure of Minhocão. The building, which had been strictly residential before the arrival of the association, accepted the exhibition after an ad-hoc negotiation, as long as security services were provided, as described by the founder activist ${ }^{7}$ in 2016:

And in the meantime, I had met the building administrator, who was my floor neighbor. He was a simple guy, a driver, he liked me from the very beginning. Then I explained everything to him, he didn't understand anything. He said: 'I don't know, we have to set a specific meeting'. The meeting was held, and nobody understood anything. Here, people are very simple people, a building a monthly maintenance fee of 350 reais per apartment. Something like that... Some said: 'Will you use the elevator a lot?' I said: 'Look, there will be security and I am willing to pay double the maintenance fee over the two months of the exhibition'. And that was the arrangement I made, to which they formally agreed. (Associação Parque Minhocão founder, 2016)

In 2014, the Association, by means of the current open channels of public participation - namely participation in the City Chamber audiences and advocacy campaigns with city councilors $^{8}$ - pressured for the inclusion of an item about the future pf Minhocão in the 2014-2024 Masterplan, via the article 375 (São Paulo, 2014). The article defined that in the following ten years Minhocão should either be demolished or maintained with a different purpose, however it should be slowly de-commissioned as an elevated highway. Following the approval of the masterplan, a specific regulatory instrument was to be discussed in the city council. It was the first time Minhocão was directly addressed in an approved urban policy since its construction. It would be the first time Minhocão would be the object of a public consultation process.

The process of revision process of the City's Masterplan opened a wide public debate regarding the future of Minhocão, its surrounding areas and, ultimately, the city's downtown area. After a few months of action, the association got support from some city councilors to present a bill that aimed at officially turning it into a park.

In February 2014, six city councilors, ${ }^{9}$ from six different - and opposing - political parties advanced Bill 10/2014, with the aim of creating the Minhocão Park and planning the deactivation of the elevated highway. According to the bill, the implementation would occur progressively through successive traffic restrictions. The bill also proposed a communal form of governance for the park's administration, defining the role of the municipality in inserting the park in its yearly cultural schedule, promoting and increasing its occupation by the population (São Paulo, 2014b).

However, by that time, the "multitude" was out. The first public hearing to discuss Bill 10/2014 (Image 1) shed light on a more complex social constellation engaged in defining the future of Minhocão. Unexpectedly, diverse and opposing groups filled the auditorium, some raising antipark signs, demanding time to speak and providing affective accounts such as the following: 
Today, when the Elevado closes at 9:30pm, there is already activity involving drug dealers and drug abuse, explicit sex and homosexuals. Imagine when this park opens? Even if it closes at 9pm, the problem will not be solved, there are homeless people and drug abusers that live below the structure. It will become another 'cracolandia' [area occupied by crack cocaine users]. The people interested [in the creation of the park] live three blocks away. It is interesting because it is not at their doorstep. (Testimonial by conservative protester in Silveira, 2014)

The speculations regarding the creation of a park were high, and yet, the June 2013 demonstrations meant that all possible sides of the political sphere were occupying and affectively re-territorializing spaces, the opportunities of public participation, and, ultimately, the public spaces in the city. It was the first time that the informal occupation of the elevated highway was contested by surrounding residents in a public debate, starting a dispute ${ }^{10}$ that is still far from being settled.

Since 2014, two anti-park groups emerged, presenting opposing voices and raising concerns about different aspects. One of the activists of the Baixo Centro movement mobilized a discussion on Facebook about the possibility of a park bringing about a gentrification process through real-estate speculation. Thus, the SP sem Minhocão

Image 1 - Unexpected anti-park public showing signs during the first public hearing for Bill 10/2014

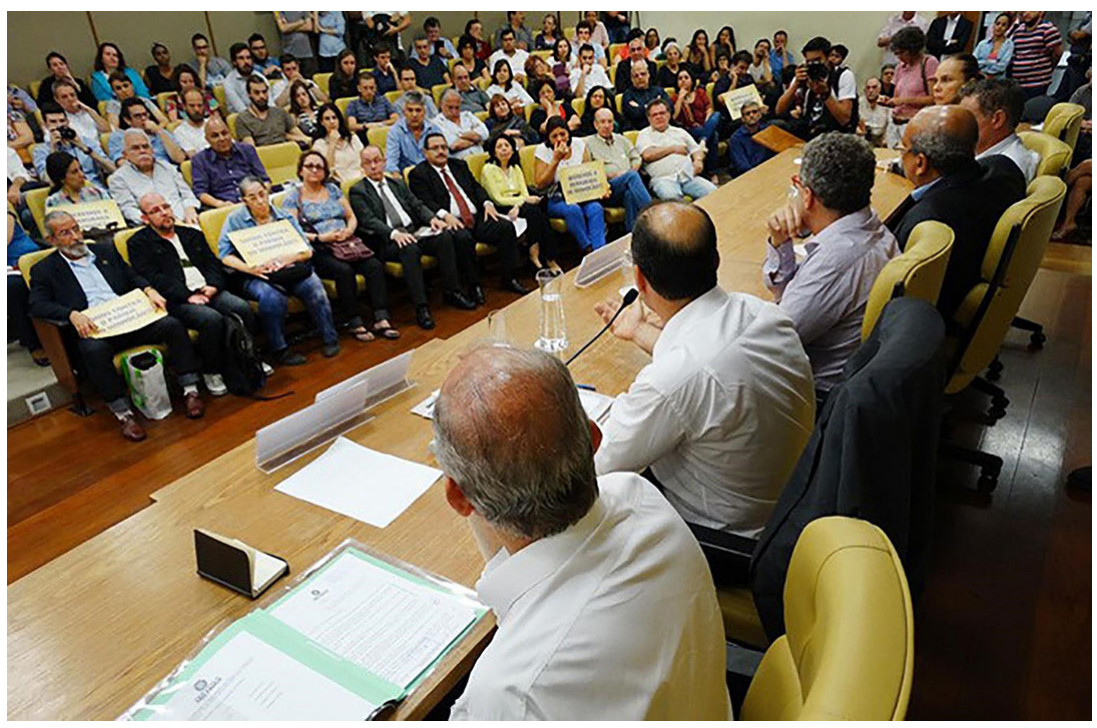

Picture: Luiz França. Source: Silveira, 2014. 
group emerged, seeking to foster a broad debate about the territorial transformation and state regulation of the area, claiming for the maintenance of the sociocultural identity of the area, to avoid the gentrification that a park could bring. The other opposition group was composed by the Desmonte Minhocão movement, supported by the neighborhood's institutionalized organizations such as Conseg Santa Cecília (Community Security Council of the neighborhood) and the Association of Residents of the Santa Cecília Neighborhood. This conservative-leaning group defended the interests of a conservative section of middle class district residents. It claimed that the removal of the enormous structure would be the most appropriate option to restore what they depicted as the "physical identity" of the area.

\section{Understanding the dispute over the future of Minhocão}

As in the June 2013 protests, opposing social groups were explicitly present in the public realm pushing for their contrasting agendas. In the discussion involving Minhocão, members of civil society were for the first time vehemently against the informal appropriation of the structure of Minhocão as a social infrastructure, increasing the complexity of its meanings in the public debate. And yet, in this dispute, they were occupying all the possible avenues, making themselves present and articulating in all available spheres. Affectively re-territorializing the public debate, each group occupied the different official instances of participation available, mobilizing the legislative, executive and judiciary powers. This dispute occurred physically, virtually, and legally, contemplating all of the abovementioned meanings of Minhocão.

The following timeline (Image 3 ) summarizes the dispute through time. The informal appropriation of Minhocão has increased in intensity and complexity since the first Baixo Centro Festival, however, we argue that the future of the structure became the object of a dispute once Bill 10/2014 was proposed by a coalition of diverse political parties. The timeline shows events and instances in which the dispute unfolded.

Since 2014, as the cultural activist groups continued to use public space for collaborative events, the groups opposing this use acted toward restricting these activities. CONSEG Santa Cecília filed a lawsuit and instructed three civil inquiries ${ }^{11}$ with the Public Ministry, denouncing the infrastructural pitfalls of the Elevado. In April 2015, they were able to prevent the use of Minhocão as part of Virada Cultural. The actions denounced the lack of safety in the informal appropriation of Minhocão, arguing that the height of the guardrail frame was inappropriate, according to current regulations for public spaces. Although no incident associated with infrastructure insecurity has been reported, the complaint succeeded in pushing the Public Ministry to prohibit the organization of all kinds of events in this open space, such as festivals, markets, and carnivals. The successive prohibitions of occupation triggered the creation of the group Ocupa Minhocão in May 2016, which advocates for the permission of events. 
Image 2 - Timeline of the urban dispute of Minhocão and its emerging social constellation

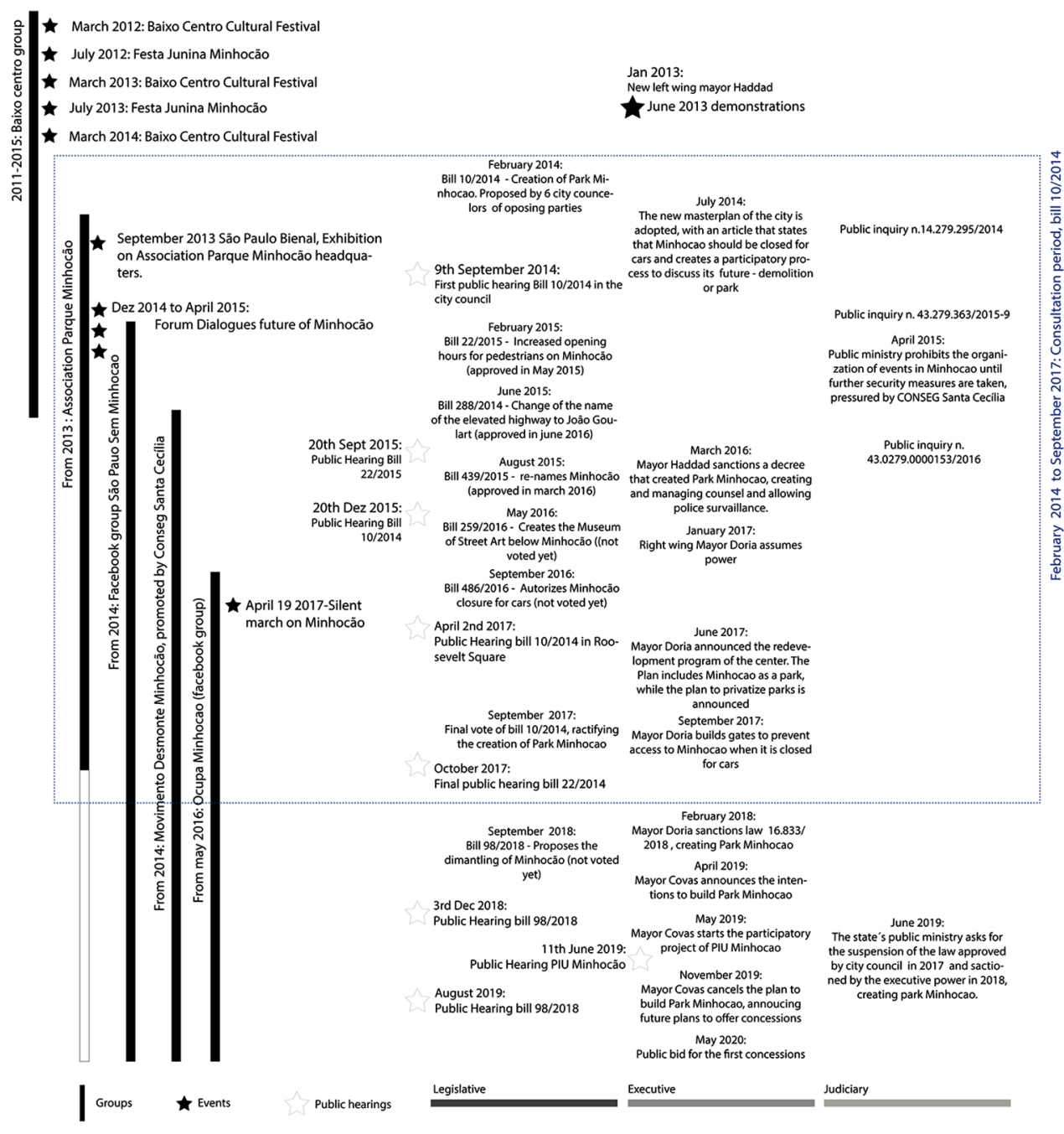

Source: devised by the authors, based on interviews, observation and data from: Redação, 2014a, 2014b, 2015a, 2015b, 2015c, 2015d, 2016a, 2016b, 2017; Werneck, 2017; Diógenes, 2016; Godoy, 2017; Pessoa, 2015; Ribeiro and Leite, 2016). 
Each of these groups, while pushing forward their agenda for Minhocão, were gathering in the public spaces in and around Minhocão, building online advocacy campaigns, while at the same time interacting with the different instances of political power. Since 2014, there have been a series of public hearings, debates, events, protests and legal actions involving the case as we can see on Image 2. Some groups, like Associação Parque Minhocão and later Ocupa Minhocão, advocated with city councilors, pushing forward several bills (São Paulo, 2015a; 2015b; 2016a; 2016b) targeting the legal transformation of Minhocão into a park, as described by an Associação Parque Minhocão activist in 2015:

It is a spontaneous and transitory park. It is a park when there aren't cars on it. [we need] to put it on people's minds, that it is already a park, or that it can be a park. This is a strategy that we found interesting. (Parque Minhocão Activist, 2015)

While pushing forward their agenda, the pro-park groups re-territorialized different public spaces in the city, such as Roosevelt Square, which, in April 2017 was used as an auditorium for a public hearing. The same space of the public hearing was affectively re-territorialized, while instead of arguing for their case when given time to speak, pro-park activists decided to sing and dance on the improvised tribune.

Other groups, particularly Desmonte Minhocão movement, operated closely with the Public Ministry, denouncing supposed irregularities in the ways the executive and legislative powers were handling the case of Minhocão. Also closely allied to the Santa Cecília Security Council (Conseg Santa
Cecilia), this group displayed a reactionary and elitist view of several of the points argued in the dispute, opposing, for instance, the assistance provided to people in situations of vulnerability, including the homeless population. As described by a Desmonte Minhocão and Conseg activist in 2013:

In fact, the assistance provided to homeless people always comes with an argument that it is differentiated work, that something better, or more elaborate will be done. But the result, and the experience over the last few years in our neighborhood, shows that it always rests on piling human beings at our doors, because they set this up as a showcase: the image of people lying in the public promenade. It is a way to address society and raise resources for the entities and the church. The help doesn't get to these people on the streets. (Metrópole Estadão, 2013)

These legal disputes, in turn, triggered reactions from civil society movements, such as the silent march held in March 2017 (Image 3), in which activists affectively re-territorialized the noisy leisure space and time on Minhocão in an act of silent political demonstration.

Additionally, anti-park groups have been re-territorializing different public hearings in the city, such as the hearings targeting PIU Central (a downtown urban project that embraces the neighborhoods impacted by Minhocão), changing the purpose of these meetings toward the affective discussion of the future of Minhocão.

Each side advanced and retreated, posed new questions, and became more politically diverse over time, in a succession of affective (re) territorializations, ranging from progressive to reactionary performances. 
Image 3 - Silence protest to maintain the use of Minhocão

as a public space for leisure on March 17, 2017

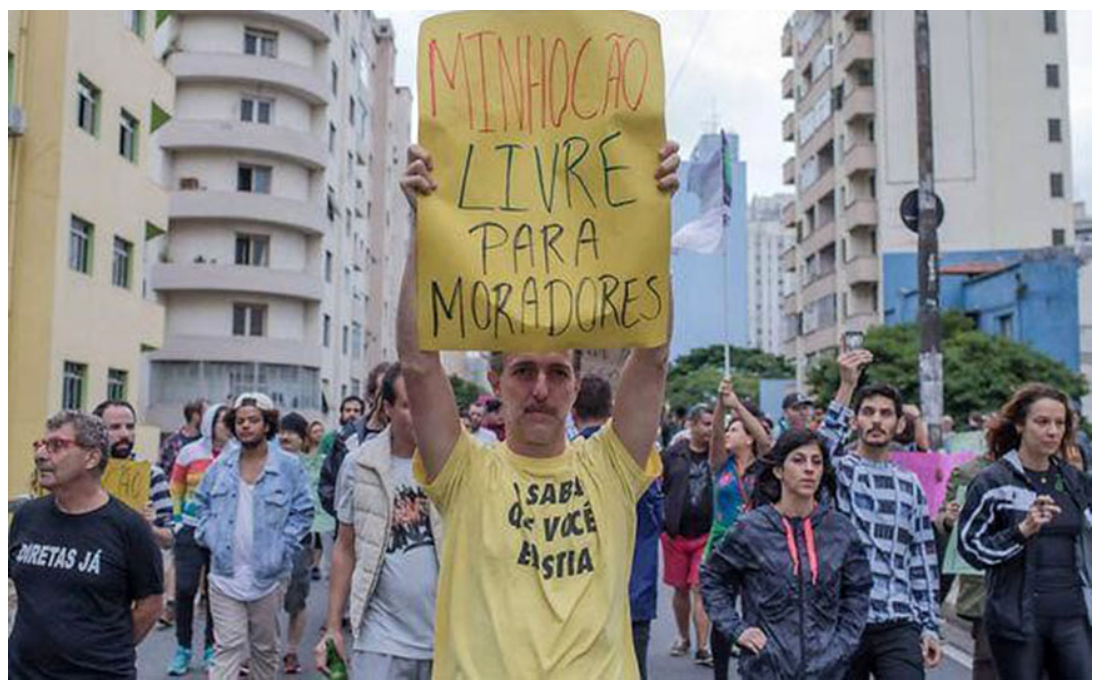

Author: Eduardo Anizelli/ Folhapress. Source: Gragnani, 2017.

The 2016 elections widened the gap between the opposing views on the city's development, reflecting the country's political divide. The left-wing Workers' Party lost the municipal elections to a neoliberal view of city management, with the victory of João Doria as the "entrepreneur mayor", a label that turned him into a leading figurehead of neoliberal rationality (Dardot and Laval, 2017; Pilotta, 2016).

As part of the Brazilian Social Democratic Party (PSDB), the leading right-wing party at the time, he based his campaign in the promise of running the city as a business, promoting a series of privatizations, a discourse and an ideal that became popular in the midst of the impeachment political crisis in Brazil. The neoliberal discourse of cutting down public expenses, shrinking the number of public servants and privatizing public services won the elections in the first term.

The first range of urban concessions announced were the public parks (Bill 16.703/2017, approved in October 2017). It was not merely coincidental that a concession to develop Minhocão Park became, in June 2017, the first announcement of what turned out to be a major project to redevelop the city's downtown area. The Centro Novo [New Downtown] project was conceived by renowned architect Jaime Lerner and funded by the Union of Real Estate companies of São Paulo (Secovi). The plan proposed the rearticulation of areas, public facilities and green commons downtown by means of a new circular light rail system, with Santa Cecília square as one of the creative economy anchor points of the downtown area. 
The announcement of the Centro Novo project caused a reaction from the Public Ministry, ${ }^{12}$ who pressured the municipality to reduce the hours open for pedestrians at Minhocão, leading to the contested idea of installing gates in its structure to prevent pedestrian access (Fuhrman, 2017). In its turn, pressured by residents and Associação Parque Minhocão, the city council voted on the bill ${ }^{13}$ that legally created Parque Minhocão and plans for its gradual closure for cars, sanctioned as law in September 2017. The text modified the 2014 bill, including the need to create an Urban Intervention Project (Projeto de Intervenção Urbana - PIU), with the possibility of turning the physical structure of Minhocão into a complete or partial park, and contemplating the creation of planning instruments to ensure its financial viability.

Since the approval of Bill 10/2014, the executive power of São Paulo changed once again, in April 2018. ${ }^{14}$ New mayor Covas announced the start of the project opening the Minhocão PIU consultation process in 2019. On May 19, 2020, the mayor of São Paulo announced a bid for the construction of eight new pedestrian accesses to the elevated highway, as the first step towards effectively turning it into a park. In parallel, in the legislative sphere, city councilors were discussing Bill 98, entered in September 2018, which proposes dismantling the structure of Minhocão after a successful advocacy campaign by the Desmonte group. This executive action inaugurates a new phase of the dispute regarding the now formalized - and under threat - uses of Minhocão. Despite the approval of Bill 10/2014 and the formalization of Park Minhocão, this urban dispute continues.

\section{Bold affects}

\section{and the re-territorializations in the urban dispute}

A spontaneous and non-organized occupation of Minhocão as an urban structure for leisure had been going on since the 1980s without major opposition until the mid-2010s. The demonstrations of June 2013 saw the political body occupying the public sphere, exposing the country's political divide. This dynamic also paved the way to an increased presence of emerging conservative groups in public debates, a presence that de-territorializes spaces and triggers, on the other hand, progressive re-territorializations mobilized by bold, public affects (Hutta, 2019). The urban dispute of Minhocão exemplifies these affective re-territorializations.

These entangled affective reterritorializations were performed not only by residents, associactivisms and various groups but also by the existing instances of power that shape the urban realm of São Paulo.

The first part of this process was the informal appropriation of this concrete piece of infrastructure by its surrounding residents. Later, the appropriation was intensified, induced by the multiplication of cultural actors intervening in this space and promoting events. With this increase of actors, Associação Parque Minhocão emerged as an important stakeholder advocating for the formalization of the existing appropriations, and for material improvements in the structure, supporting these activities. This advocacy campaign culminated on Bill 10/2014, inaugurating the urban dispute in the public sphere. New groups and movements emerged, opposing 
both the idea of the creation of a park and the informal and induced appropriations, eventually advocating for the demolition or dismantling of the structure.

The case demonstrates how opposing political bodies occupied the public spheres of debate and participation, exploring the roles of the three political instances (executive, legislative and judiciary). Meanwhile, neoliberalization processes unraveled the dispute, aiming to formalize the appropriations and the idea of a park when parks and other public equipment were set to be privatized in the city and amidst a process of commodification of cultural activities and public spaces. Therefore, ultimately, the formalization of the spontaneous activities that took place in this open space triggered the possibility of its enclosure. We propose that the dispute around Minhocão exemplifies how bold affects are re-territorializing virtual and physical spaces of the public sphere, mobilizing progressive and conservative affects, joy and resentment, impacting how the idea of public space is shaped in contemporary cities, as a consequence of the uprisings of the early 2010 s.

The first re-territorializing mobilized joy, amusement, and hope, when Baixo Centro promoted its first events, changing the way Minhocão was inhabited and mobilizing the imagination of a multitude of groups and individuals. Later, consecutive deterritorialization happened in the different spheres of public consultation, mobilizing fear and discontent with the idea of formalizing the appropriations of Minhocão, led by a coalition of progressive (SP sem Minhocão) and conservative (Desmonte Minhocão) ideologies.
During this dispute, left-leaning and right-leaning groups became more complex, with the diversification of its participants. The rise in performed bold affects, in different instances of the public realm (both in public spaces and in the spaces of public consultation), mobilized this urban dispute, permeated by increasing neoliberalization, with the creation of the urban project Centro Novo and later the PIU Minhocão.

Regarding this dispute, we stress that leisure activities had already been occurring in the elevated highway for decades, as spontaneous and day-to-day activities. Increasingly, from 2012 onward, new groups of actors emerged, intensifying these daily occupations, which acquired a festive character, based on events that went beyond the day-to-day character. According to Butler (2015), a ritualistic assembly of bodies on the streets is an action that creates a location, a political space. The sequence of events, assembling a multitude of bodies on Minhocão created a new political space in the city, turning it into the target of a dispute. From the creation of this political space, a social constellation emerged. This constellation is diverse in its political orientation, impacting how the different groups positioned themselves within the dispute: some groups were in favor of the appropriation of the elevated highway (Baixo Centro, Associação Parque Minhocão, Ocupa Minhocão), some were in favor of formalizing these activities and turning the structure into a park (Associação Parque Minhocão, Ocupa Minhocão). Others have opposed the formalization of the structure into a Park (SP sem Minhocão) and some, ultimately, were against the spontaneous appropriations of the structure itself (Desmonte Minhocão). 
All groups occupied in one way or another the existing online and offline channels of public participation in the city, maintaining a visible position in the public sphere (social media, online consultations, blogs, traditional media and public hearings). Beyond maintaining these visible positions, the institutionalized groups (Associação Parque Minhocão, the Association of Santa Cecília Residents and the Conseg) took advantage of their status, increasing their advocacy initiatives within the legislative and judiciary powers by promoting legal advocacy and starting legal actions.

However, only the groups that were in favor of maintaining the appropriations acted physically in the public spaces of the city, aggregating bodies in the open space under dispute, therefore creating a new political space, which makes a fundamental difference. They were the groups that mobilized the "multitude", as pointed by Monteiro (2018). The groups against the spontaneous appropriations advocated for the prohibition of a social phenomenon that already occurred in an open space, however informally. Therefore, they advocated for diminishing rights and for the reduction of spaces of communal use in the city. Meanwhile, the groups that advocated for the creation of the park had in mind the formalization of this space for communal use into an official public commons. In this sense, we understand that the former acted conservatively (limiting rights and public spaces) and the latter acted progressively (expanding rights and public spaces). This duality becomes more complex when we understand this case within neoliberalization processes, while different groups and the public administration are aiming to take advantage of the formalization of the park to enable its enclosure for private events, monetizing some of the activities promoted on it.

The appropriation of Minhocão, while creating the infrastructure in which bodies assemble, created a political space. Formalized or not, this structure became a support, a new (physical) space of the public sphere. Proposing its closure or - ultimately -its dismantling is an example of commons enclosure, the enclosure of a political space, since, according to Butler (2015), the very constitution of the public sphere is the "condition of appearing" (p. 21), the physical structures that allow for "being there", the infrastructure for assembling.

\section{Final remarks}

This paper, while focusing on the case of Minhocão, an elevated highway in São Paulo that is being transformed into a park, analyzes contemporary urban disputes and how they unfold after the urban uprisings of the 2010s. The demonstrations of June 2013 in Brazil have shaped the way different constellations of progressive and conservative actors have been occupying public spaces and public spheres of participation in Brazil. The case of Minhocão showed a constellation of different stakeholders emerging in dispute, occupying and affectively re-territorializing the public realm and the urban debate. They formed very fluid and diverse advocacy coalitions to pressure the distinct instances of power at hand. The resulting accomplishments were undertaken through the performance of bold affects aimed at pushing different and contrasting agendas in each of these moments. 
In São Paulo, Minhocão can be seen as a portal for urban trends, ranging from a poster case of social appropriation, urban creativity, and activism, to the commodified image of neoliberalization and gentrification processes. This case exemplifies the current debates and experiences of participation and occupation of the public realm by an increasingly diverse political body in the city, as well as the contrasting roles played by the different instances of governmental power - executive, legislative and judiciary - when it comes to supporting participatory processes in the city's development waves. The trajectory of this urban transformation is a complex subject, and this space's story will not be free from either virtual or physical urban disputes in the future. It is still an ongoing process.

Analyzing the case, we observed that different groups, representing a plurality of ideologies, employed different strategies in their performances of affective reterritorialization in all the physical and virtual spaces of the public sphere. The group Baixo Centro took action by supporting the culture of appropriation of the urban space. The Associação Parque Minhocão achieved changes in urban regulation using tactics of advocacy, building political alliances, and occupying the existing official spaces of participation in the city council. The progressive Minhocão Sem Medo and Ocupe Minhocão, whose activities are mainly online, took action by delivering information to its members, working with online advocacy and awareness campaigns. Meanwhile, the conservative movement Desmonte Minhocão, through the Santa Cecilia Security Council, was able to hinder its appropriation for leisure judicial activism, mobilizing the state's Public Prosecutor's Office with a chain of complaints.

The case of Minhocão represents the recovery of the discourse on civic appropriation of urban spaces as much as a new wave of neoliberalization within the fields of urban policy and urban planning, empowered by right-wing populism.

Since the demonstrations of June 2013, the public spaces in Brazil have been used in different ways by citizens representative of opposing political discourses, from appreciation and support of initiatives of appropriation of urban spaces by residents, to their conversion into political marketing schemes, used to advertise agendas of privatization. This paper uncovers how opposing and diverse groups, progressive and conservative, have organized formally and informally, physically and virtually, mobilizing the masses and occupying the existing spheres and channels of participation, pushing their contrasting demands, consolidating their presence in the public sphere and shedding light on the contemporary debate.

This paper advances literature in the field by identifying that the re-territorialization and the affects performed and mobilized in the demonstrations of the early 2010s have taken hold and are now incorporated as daily political action in the context of contemporary urban disputes. Moreover, as suggested by Sandler (2020), contemporary grassroots forms of urbanism have been informing urban policies since the mid-2000s, a process that is not exclusive to the Brazilian context. The analysis of how the urban dispute of Minhocão unfolded in the process of policy-making can 
provide useful information for similar cases of urban dispute undertaken through the performance of bold affects.

In São Paulo, a good portion of the recent artistic appropriations of public spaces, and later the strategies of political and judicial action to prevent that, happened around the urban dispute of Minhocão. By undertaking successive affective re-territorializations on the different instances of participation, the diverse groups put pressure on the state and, at the same time, acted with a certain autonomy from the state. Technology of information proved a crucial element in this contemporary process, virtually gathering people that share a common cause to perform different kinds of bold affects. Institutions and public power have been conflictingly reacting to this change.

Brazil is maturing as a democratic society whose participatory spheres are constantly under threat. Despite not always being inclusive, civil society organizations and associactivism groups have played an increasingly important role in urban politics and policies, being able to promote debate and eventually actual changes in existing urban spaces. Yet, the voluntarist practice of diverse groups lacks state mechanisms that guarantee their achievements within society itself.

\section{[I] https://orcid.org/0000-0003-2682-1870}

Federal University of Bahia, Faculty of Architecture and Urbanism, Advanced Program in Architecture and Urbanism. Salvador, BA/Brasil.

queirozeliana@outlook.com

\section{[II] https://orcid.org/0000-0002-8756-6191}

Nove de Julho University, Smart and Sustainable Cities Master Program. São Paulo, SP/Brasil. cintiacmarino@gmail.com

Translation: the article was translated by Maíra Mendes Galvão - mairamendesgalvao@gmail.com 


\section{Notes}

(1) Known by its many road-based interventions, Maluf's rhetorical strategy around the construction of Minhocão involved highlighting his competence in materializing infrastructure in the city, making his mandate notorious among conservative supporters to this day.

(2) As a place for political existence (Butler, 2016; Habermas, 1984), debate, participation and interaction between citizens, institutions, private investors and the state, the concept of the public sphere is often exclusionary and is not self-evident. It requires the social and spatial "conditions of appearance" (Butler, 2016), depending on the performance of citizens seeking a form of self-expression (Sennett, 2016; Kluge and Negt, 2016).

(3) Laval and Dardot (2017) conceptualize neoliberalism as not just an ideology or a prescription for economic policy, but a new reason, the internal corrosion of the public sphere and the democratic dimension itself. We refer to this process as neoliberalization (Pinson \& Journal, 2016), comprising a political process, a new regime of conviviality that governs the relations between state, market and civil society.

(4) Space production, as a historical process, is the result of the articulation of political and economic forces of different actors (Lefebvre, 1972).

(5) Participant observation was carried out from November 2011 to September 2013.

(6) The website operated between 2013 and 2018.

(7) Key interviewees identity will remain anonymous due privacy concerns.

(8) The architect and urbanist Nabil Bonduki, known academic and a city councilor from the Workers' Party (PT) by then, oversaw the Materplan's revision in the City Chamber was a founding member of the association.

(9) José Police Neto (PSD), Nabil Bonduki (PT), Toninho Vespoli (PSOL), Ricardo Young (PPS), Goulart (PSD) e Natalini (PV).

(10) We consider the current dispute that is the object of this paper as having started in this public hearing, acknowledging, however, that a wider, structural and class-based dispute has been unfolding in the downtown region of São Paulo for decades. Although relevant, this wider dispute is not the object of the current paper.

(11) Civil Inquiries n. 43.0279.0000153/2016; n. 43.279.363/2015-9; and n. 14.279.295/2014.

(12) The Public Prosecutor's Office mentioned is from the state level.

(13) Municipal São Paulo Act n. 16.833/ 2018 sanctioned, on the basis of Bill n. 10/2014, on September 20, 2017, followed by the last public hearing that took place on October 22, 2017.

(14) After one year and three months at the City Hall, mayor João Doria left it to run for the government of the state of São Paulo. 


\section{References}

ARTIGAS, R.; MELLO, J.; CASTRO, A. P. (2008). Caminhos do elevado: memória e projetos. São Paulo, Imprensa Oficial do Estado de São Paulo, Secretaria Municipal de Planejamento.

ASSOCIAÇÃO PARQUE MINHOCÃO ACTIVIST (2015). Interviewed by Cintia Marino. São Paulo, 20 nov. ASSOCIAÇÃO PARQUE MINHOCÃO FOUNDER (2016). Interviewed by Cintia Marino. São Paulo, 06 oct. BAIXO CENTRO (2013). Passos para dançar. Flyer.

BAIXO CENTRO ACTIVIST (2017). Interviewed by Cintia Marino. São Paulo, 22 nov.

BARBOSA, E. R. de Q. (2012). Minhocão Multiples Interpretations. Arquitextos, São Paulo, year 13, n. 147.03. Available at: <https://vitruvius.com.br/revistas/read/arquitextos/13.147/4455/en>. Accessed: August 30, 2020.

BAUMAN; Z.; MAURO, E. (2018). Babel. London, John Wiley \& Sons.

BUTLER, J. (2015). Notes toward a performative theory of assembly. Cambridge, Harvard University Press.

CARLOS, A. F. A. (2014). O poder do corpo no espaço público: o urbano como privação e o direito à cidade. GEOUSP Espaço e Tempo. São Paulo, v. 18, n. 3, pp. 472-486.

CASTELLS, M. (2015). Networks of outrage and hope: Social movements in the Internet age. London, John Wiley \& Sons.

CATARSE; CHORUS (2014). Retrato financiamento coletivo Brasil 2013/2014. (Report). Sao Paulo. Available at: http://pesquisa.catarse.me/\#/02, Accessed: September 11, 2019.

COHEN, J.; ROGERS, J. (1995). Associations and democracy. London, Verso.

COMOLATTI, A.; SENA, J.; VON POSER, P.; LEVY, W. (2014). O Parque Minhocão e a alma da cidade. Minha Cidade. São Paulo, ano 14, n. 166.01. Available at: www.vitruvius.com.br/revistas/read/ minhacidade/14.166/5154. Accessed: July 13, 2020.

DARDOT, P.; LAVAL, C. (2017). A nova razão do mundo. Boitempo.

DIÓGENES, J. (2016). Haddad sanciona lei que cria Parque Minhocão e diz que via é um erro. O Estado de S.Paulo, March 9. Available at: https://sao-paulo.estadao.com.br/noticias/geral,haddadsanciona-lei-que-cria-parque-minhocao-e-diz-que-via-e-um-erro,10000020326. Accessed: July 13, 2020.

FUHRMAN, L. (2017). Doria instala portões no Minhocão para evitar acesso de pedestres à noite. Folha de S.Paulo. September 2. Available at: https://www1.folha.uol.com.br/cotidiano/2017/09/1915222prefeitura-de-sp-instala-portoes-para-limitar-o-acesso-ao-minhocao-a-noite.shtml. Accessed: July 13, 2020.

GODOY, A. (2017). Audiência Pública debate criação do Parque Minhocão. Notícias Câmara Municipal de São Paulo. October 22. Available at: http://www.saopaulo.sp.leg.br/blog/audiencia-publicadebate-criacao-do-parque-minhocao/. Accessed: July 13, 2020.

GORSKI, M. (2005). Abaixo o elevado! O desmonte do Elevado Costa e Silva e o efeito catalisador para a revitalização do Centro. Minha Cidade. São Paulo, ano 6, n. 061.02. Available at: www.vitruvius. com.br/revistas/read/minhacidade/06.061/1970. Accessed: August 30, 2020. 
GRAGNANI, J. (2017). Grupo faz protesto silencioso contra restrição de pedestres no Minhocão. Folha de S.Paulo. March 19. Available at: https://www1.folha.uol.com.br/paywall/signup.shtml?https:// www1.folha.uol.com.br/cotidiano/2017/03/1867928-grupo-faz-protesto-silencioso-contrarestricao-de-pedestres-no-minhocao.shtml. Accessed: July 13, 2020.

HABERMAS, J (1984). Mudança estrutural da esfera pública. Rio de Janeiro, Tempo Brasileiro.

HAESBAERT, R. (2013). “A global sense of place and multi-territoriality. Notes for dialogue from a 'peripheral'point of view". In: FEATHERSTONE, D.; PAINTER, J. (eds.). Spatial Politics: essays for Doreen Massey. London, Wiley-Blackwell, Chichester.

HARVEY, D. (2008). The Right to the City. New Left Review, v. 53, n. 23, pp. 23-40.

(2012) Rebel cities: from the right to the city to the urban revolution. London/New York, Verso.

HIRST, P. (1994). Associative democracy: new forms of economic and social governance. Amherst, MA, University of Massachusetts Press.

(2001) “Can associationalism come back?” In: HIRST, P.; VEIT, B. (eds.). Associative democracy: the real third way. New York, Taylor \& Francis.

HUTTA, S. (2019). Affective territorialities in Brazil's current political conjuncture: a three-part essay. Society and Space. Essays, April 11. Available at: https://www.societyandspace.org/articles/ affective-territorialities-in-brazils-current-political-conjuncture-a-three-part-essay. Accessed: July 13, 2020.

KLUGE, A.; NEGT, O. (2016). Public sphere and experience: analysis of the bourgeois and proletarian public sphere. New York, Verso.

LEFEBVRE, H. (1972). Le droit à la ville. Suivi de Espace et politique. Paris, Anthropos.

LEVY, W. (2014). Esfera pública, interesse público e o Parque Minhocão. Arquitextos. São Paulo, ano 14, n. 165.06. Available at: http://www.vitruvius.com.br/revistas/read/arquitextos/14.165/5086. Accessed: July 13, 2020.

(2015). Parque Minhocão. Cidade e democracia: novas perspectivas. Minha Cidade. São Paulo, ano 15, n. 175.04. Available at: http://www.vitruvius.com.br/revistas/read/ minhacidade/14.175/5431. Accessed: July 13, 2020.

MARICATO, E. et al. (2013). Cidades rebeldes: Passe Livre e as manifestações que tomaram as ruas do Brasil. São Paulo, Boitempo.

MARINO, C. (2019). Ativismo e apropriação do espaço urbano em São Paulo. Arq.Urb, n. 23, pp. 170-184. Available at: https://revistaarqurb.com.br/arqurb/article/view/46. Accessed: January 5, 2021.

METRÓPOLE ESTADÃO (2013). Interview with Fabio Fortes - presidente do Conseg Santa Cecília. Interview by Metrópole. Estadão, May 29. Available at: https://www.youtube.com/watch?v=hbll_ at7Cgw\&t=25s. Accessed: July 13, 2020.

MIRAFTAB, F. (2009). Insurgent Planning: situating radical planning in the global south. Planning Theory, v. 8, n. 1, pp. 32-50. Avbailable at: https://doi.org/10.1177/1473095208099297. Accessed: August 8, 2020.

(2016). Insurgência, planejamento e a perspectiva de um urbanismo humano. Revista Brasileira de Estudos Urbanos e Regionais, v. 18, n. 3, pp. 363-377. 
MONTEIRO, M. (2018). 'De pedra e pau': etnografia do levante popular de junho de 2013 na cidade do Rio de Janeiro e suas continuidades. PhD Thesis. Florianópolis, Universidade Federal de Santa Catarina.

PESSOA, G. S. (2015). Após acordo no Ministério Público, prefeitura exclui Minhocão da Virada. Folha de S.Paulo, June 18. Available at https://www1.folha.uol.com.br/paywall/adblock.shtml?origin =after\&url=https://m.folha.uol.com.br/ilustrada/2015/06/1644899-apos-acordo-no-ministeriopublico-prefeitura-exclui-minhocao-da-virada.shtml?loggedpaywall. Accessed: July 13, 2020.

PILOTTA, J. J. (2016). "The entrepreneur as hero?” In: BERDAYES, V.; MURPHY, J. (eds.). Neoliberalism, economic radicalism, and the normalization of violence. New York, Springer, Cham.

PINHEIRO-MACHADO, R. (2019). Amanhã vai ser maior - O que aconteceu com o brasil e possíveis saídas para a crise atual. São Paulo, Planeta do Brasil.

PINSON, G.; JOURNEL, C. M. (2016). Beyond neoliberal imposition: state-local cooperation and the blending of social and economic objectives in French urban development corporations. Territory, Politics, Governance, v. 4, n. 2, pp. 173-195.

PINTO, C. R. J. (2017). A trajetória discursiva das manifestações de rua no brasil (2013-2015). Lua Nova: Revista de Cultura e Política, n. 100, pp. 119-153.

PORTAL VITRUVIUS (2006). Prêmio Prestes Maia de Urbanismo/2006. Projetos, ano 6, n. 067.02, Available at: www.vitruvius.com.br/revistas/read/projetos/06.067/2689. Accessed: July 13, 2020.

(2016). A marquise do Minhocão. Projetos, ano 16, n. 183.04. Available at: www.vitruvius.com. br/revistas/read/projetos/16.183/5971. Accessed: July 13, 2020.

QUEIROZ, C. (2017). Conseg, Minhocão, Ministério Público e Prefeitura Regional Sé. Movimento Desmonte do Minhocão. April $1^{\text {st }}$. Available at: https://www.minhocao.net.br/conseg-minhocaoministerio-publico-e-prefeitura-regional-se/. Accessed: July 13, 2020.

REDAÇÃO CÂMARA MUNICIPAL DE SÃO PAULO (2014a). Audiência Pública vai debater transformação do Minhocão em parque. Notícias Câmara Municipal de São Paulo, September 8. Available at: http://www.saopaulo.sp.leg.br/blog/audiencia-publica-vai-debater-transformacao-dominhocao-em-parque/. Accessed: July 13, 2020.

(2014b). Minhocão é "cicatriz" no coração de São Paulo, diz Police. Notícias Câmara Municipal de São Paulo, February 14. Available at: http://www.saopaulo.sp.leg.br/blog/minhocao-ecicatriz-no-coracao-de-sao-paulo-diz-police/. Accessed: July 13, 2020.

(2015a). Audiência pública sobre fechamento do Minhocão é adiada. São Paulo, Camara Municipal de São Paulo.

(2015b). Câmara realizará audiência para discutir fechamento do Minhocão. Notícias Câmara Municipal de São Paulo, September 18. Available at: http://www.saopaulo.sp.leg.br/blog/ audiencia-publica-sobre-fechamento-do-minhocao-e-adiada/. Accessed: July 13, 2020.

(2015c). Frente Parlamentar discute futuro do Minhocão. Notícias Câmara Municipal de São Paulo, December 3. Available at: http://www.saopaulo.sp.leg.br/blog/frente-parlamentardiscute-futuro-do-minhocao/. Accessed: july 13, 2020.

(2015d). Projeto aprovado fecha Minhocão aos sábados. Notícias Câmara Municipal de São Paulo, May 12. Available at: http://www.saopaulo.sp.leg.br/blog/projeto-aprovado-fechaminhocao-aos-sabados/. Accessed: July 13, 2020. 
REDAÇÃO CÂMARA MUNICIPAL DE SÃO PAULO (2016a). Especial Minhocão - Minhocão, um quarentão de futuro incerto. Notícias Câmara Municipal de São Paulo, March 18. Available at: http://www. saopaulo.sp.leg.br/especiaiscmsp/especial-minhocao/. Accessed: July 13, 2020.

(2016b). Prefeitura sanciona lei que cria o Parque Minhocão. Notícias Câmara Municipal de São Paulo, March 10. Available at: http://www.saopaulo.sp.leg.br/blog/prefeitura-sanciona-lei-quecria-o-parque-minhocao/. Accessed: July 13, 2020.

(2017). Audiência pública discute horário de funcionamento do Parque Minhocão. Notícias Câmara Municipal de São Paulo, March, 31. Available at: http://www.saopaulo.sp.leg.br/blog/ audiencia-publica-discute-horario-de-funcionamento-do-parque-minhocao/. Accessed: july 13, 2020.

RIBEIRO, B.; LEITE, F. (2016). MP pede proibição de pedestres e ciclistas no Minhocão. O Estado de S.Paulo, April 26. Available at: https://sao-paulo.estadao.com.br/blogs/por-dentro-dametropole/mp-pede-proibicao-de-pedestres-e-ciclistas-no-minhocao/. Accessed: July 13, 2020.

SANDLER, D. (2020). Grassroots urbanism in contemporary São Paulo. Urban Design International, v. 25, n. 1, pp. 77-91.

SANTOS, B. S. (2015). Revueltas de indignación y otras conversas. Sucre, Stigma.

SÃO PAULO (CÂMARA MUNICIPAL) (2014). Parque Minhocão bill (Bill n. 10/2014). São Paulo, Câmara Municipal de São Paulo.

(2015a) Bill n. 22/2015. São Paulo, Câmara Municipal de São Paulo.

(2015b). Bill n. 439/2015. São Paulo, Câmara Municipal de São Paulo.

(2016a) Bill n. 259/2016. São Paulo, Câmara Municipal de São Paulo.

(2016b). Bill n. 486/2016. São Paulo, Câmara Municipal de São Paulo.

SÃo PAULO (PREFEITURA MUNICIPAL) (2013). Chamamento público n. 1/2013/SMDU. São Paulo, Prefeitura de São Paulo/SMDU.

(2014). Plano Diretor do Município de São Paulo. Law no 16.05/2014. São Paulo, Câmara Municipal de São Paulo.

(2016) Arco Tietê: cenários de desenvolvimento. São Paulo, Prefeitura de São Paulo/ SPUrbanismo.

SCHWARCZ, L. M.; STARLING, H. M. (2015). Brasil: uma biografia: com novo pós-escrito. São Paulo, Companhia das Letras.

SILVEIRA, J. (2014). Transformação do Minhocão em parque gera polêmica em audiência. Noticias Câmara Municipal de São Paulo, September 9. Available at: http://www.saopaulo.sp.leg.br/blog/ transformacao-do-minhocao-em-parque-gera-polemica-em-audiencia/. Accessed: July 13, 2020.

SOUZA, M. J. L.; RODRIGUES, G. B. (2004). Planejamento urbano e ativismos sociais. Bauru, Unesp.

VAINER, C. (2013). "Quando a cidade vai às ruas". In: HARVEY, D. et al. Cidades Rebeldes: Passe livre e as manifestações que tomaram as ruas do Brasil. São Paulo, Boitempo.

WARREN, M. E. (2001). Democracy and association. New Jersey, Princeton University Press. 
WERNECK, M. R. (2017). População se reúne para discutir funcionamento do Parque Minhocão. Noticias Câmara Municipal de São Paulo, April 3. Available at: https://www.saopaulo.sp.leg.br/ blog/populacao-se-reune-para-discutir-funcionamento-do-parque-minhocao/. Accessed: July 13, 2020.

WISNIK, G. (2016). Ativismo urbano para uso do espaço público se choca com regressão política. Jornal da USP, April 6. Available at: http://jornal.usp.br/atualidades/ativismo-urbano-para-uso-doespaco publico-se-choca-com-regressao-politica/. Accessed: September 11, 2019.

ŽIŽEK, S. (2012). O ano em que sonhamos perigosamente. São Paulo, Boitempo.

Received: August 30, 2020

Approved: November 25, 2020 
